\title{
Lowering the potential of electroenzymatic glucose oxidation on redox hydrogel-modified porous carbon electrode
}

\author{
Aimi Suzuki ${ }^{\mathrm{a}}$, Nicolas Mano ${ }^{\mathrm{b}}$, Seiya Tsujimura ${ }^{\mathrm{a}, *}$ \\ a Division of Materials Science, Faculty of Pure and Applied Sciences, University of Tsukuba, 1-1-1 Tennodai, Tsukuba, Ibaraki 305-8573, Japan \\ ${ }^{\mathrm{b}}$ Centre de Recherche Paul Pascal, CRPP-UPR 8641-CNRS, Univ. Bordeaux, Avenue Albert Schweitzer, Pessac, France
}

\begin{abstract}
Herein, we demonstrate high current densities per projected surface area for the electroenzymatic oxidation of glucose at low potential using a hierarchically structured electrode based on MgO-templated carbon. The modified electrode was prepared by assembling glucose oxidase (GOx) with an osmiumbased redox polymer with a low formal potential $(-0.03 \mathrm{~V}$ vs. $\mathrm{Ag} \mid \mathrm{AgCl})$, in which Os complexes are tethered to the polymer backbone via a 13-atom alkyl chain and a crosslinker. A glucose oxidation current density of $15 \mathrm{~mA} \mathrm{~cm}^{-2}$ was measured at $0 \mathrm{~V}$ vs. $\mathrm{Ag} \mid \mathrm{AgCl}$ at $37^{\circ} \mathrm{C}$ and $\mathrm{pH} 7$, with a plateau value of $50 \mathrm{~mA} \mathrm{~cm}^{-2}$ at $0.3 \mathrm{~V}$. The hydrogel electrodes composed of the same redox polymer and FAD-dependent glucose dehydrogenase delivered only $10 \%$ of the current densities obtained with the GOx electrode.
\end{abstract}

\author{
Keywords: \\ Glucose oxidase \\ redox hydrogel \\ porous carbon \\ biofuel cell
}

\section{Introduction}

We recently reported the development of a glucose-oxidizing electrode using MgO-templated mesoporous carbon (MgOC), with an average pore diameter of $38 \mathrm{~nm}$, as an electrode material. The $\mathrm{MgOC}$ was coated with a hydrogel containing a redox polymer, glucose oxidase (GOx), as well as FAD-dependent glucose dehydrogenase (FADGDH) [1,2]. With the objective of improving the mass transfer of fuel and electrolyte ions through the porous carbon layer, porous carbon particles were deposited on a glassy carbon substrate by an electrophoretic technique, to form $10 \mu \mathrm{m}$ scale macropores. The hydrogel, composed of a redox polymer, partially quaternized poly(1-vinylimidazole) complexed with [Os (bipyridine) ${ }_{2} \mathrm{Cl}$ ] (polymer I, $E^{\circ}=0.22 \mathrm{~V}$ vs. $\mathrm{Ag} \mid \mathrm{AgCl}$ ) [3,4], GOx, and a crosslinker, produced glucose oxidation current densities as high as $60 \mathrm{~mA} \mathrm{~cm}^{-2}$ at $0.7 \mathrm{~V}$ at $37^{\circ} \mathrm{C}$. This current density is 12 times higher than that obtained with the same polymer on a glassy carbon electrode (GC-E). For comparison with other GOx-hydrogelbased electrodes, the effect of the hierarchical structure of the MgOC-based electrode can be elucidated using polymer I, which has been used on other porous carbon materials [4-6]. Similar hydrogel-modified porous carbon electrodes, composed of the same redox polymer and deglycosylated FADGDH, have achieved current densities of $180 \mathrm{mAcm}^{-2}$ at $0.7 \mathrm{~V}$ and $37^{\circ} \mathrm{C}$, which is 3

\footnotetext{
* Corresponding author.

E-mail address: seiya@ims.tsukuba.ac.jp (S. Tsujimura).
}

times higher than current densities for GOx-based electrodes [2]. However, this electrode system was far from optimum, because the redox mediator potential was too high for use in efficient biosensors and biofuel cells (BFCs) [7]. A redox mediator with a lower potential is required to avoid the electrochemical oxidation of interfering substances, to achieve high accuracy sensors, and to increase the operational voltage of BFCs [8-10]. Mano et al. developed redox polymers with lower redox potentials [11]. The rate of electron transfer from the active center of GOx, FAD, to the Os complex tethered to the polymer backbone was reported to increase as the potential difference between the two species increased. This paper also reported that $\mathrm{O}_{2}$ can be reduced on these polymers to produce $\mathrm{H}_{2} \mathrm{O}_{2}$, with an $E^{\circ}$ ' value lower than $+0.07 \mathrm{~V}$ vs. $\mathrm{Ag} \mid \mathrm{AgCl}$; the rate of this reaction increased exponentially with decreasing $E^{\circ}$ '.

Therefore, in this study we selected a redox polymer (polymer II), which consists of poly(vinyl pyridine) complexed with $\mathrm{Os}\left(1,1^{\prime}-\right.$ dimethyl-2,2'-biimidazole) $)_{2}$-2-[6-methylpyrid-2-yl]imidazole $)^{2+/ 3}$ ${ }^{+}[11-13]$. This polymer has a redox potential of $-0.03 \mathrm{~V} \mathrm{vs}$. $\mathrm{Ag} \mid \mathrm{AgCl}$ and allows GOx to produce an efficient glucose oxidation current $\left(2.5 \mathrm{mAcm}^{-2}\right)$ on a GC-E at $37^{\circ} \mathrm{C}$, with a hydrogel loading of $200 \mu \mathrm{g} \mathrm{cm}^{-2}$ [12]. To achieve further enhancement in current density, Ketjen Black (KB, a type of carbon black with $800 \mathrm{~m}^{2} \mathrm{~g}^{-1}$ of high specific surface area) [12] and a three-dimensional carbonaceous foam [13] were used as potential porous electrode materials in order to increase the efficiency of the enzymatic anode. The KBmodified electrode, with $200 \mu \mathrm{g} \mathrm{cm}^{-2}$ of hydrogel loading, produced $8 \mathrm{mAcm}^{-2}$ of catalytic current density at $37^{\circ} \mathrm{C}$ and 
$6000 \mathrm{rpm}$, while the latter porous carbonaceous electrode, with $1734 \mu \mathrm{g} \mathrm{cm}^{-2}$ of hydrogel loading, produced $18 \mathrm{~mA} \mathrm{~cm}^{-2}$ at $37^{\circ} \mathrm{C}$ and $2000 \mathrm{rpm}$. However, the enhancement in catalytic current achieved using these porous structured carbon electrodes was quite limited. The past studies of glucose anode based on hydrogelporous carbon are summarized in Table 1.

To circumvent this limitation, in this study, hydrogels with polymer II and GOx or FADGDH were prepared on hierarchically structured MgOC-based porous electrodes. The present work shows that high catalytic currents at low redox potentials can be obtained for GOx immobilized with a polymer II-based hydrogel matrix, without a significant decrease in electroenzymatic current for glucose oxidation. Surprisingly, although FADGDH has a superior electron exchange ability over GOx toward polymer I [14], polymer II was found not to be able to connect efficiently to FADGDH.

\section{Experimental}

The MgO-templated carbon-modified electrode (MgOC-E) was fabricated according to our previous papers [1,2]. MgO-templated carbon, with an average pore diameter of $38 \mathrm{~nm}$, was kindly donated by Toyo Tanso (CNovel ${ }^{\mathbb{R}}$, Osaka, Japan). The mixed biocatalyst solution was composed of enzyme, GOx (from Aspergillus niger, Wako Pure Chemical, $40 \mathrm{mg} \mathrm{mL}^{-1}$ ) or FADGDH (from Aspergillus terreus, Ikeda Thoka, $40 \mathrm{mg} \mathrm{mL}^{-1}$ ), redox polymer II $\left(8 \mathrm{mg} \mathrm{mL}^{-1}\right)$, and a crosslinker, poly(ethylene glycol) diglycidyl ether (PEGDGE, molecular weight 500, Sigma-Aldrich, $8 \mathrm{mg} \mathrm{mL}^{-1}$ ). The total hydrogel loading on the electrode surface was fixed at $1000 \mu \mathrm{g} \mathrm{cm}^{-2}$. The percentage weight of the crosslinker for total hydrogel loading was varied $(10,15,20,30 \%$ relative to the total hydrogel), while maintaining a constant $(1: 1)$ ratio of enzyme to polymer II. This biocatalyst solution was pipetted onto the MgOC-E surface, which was conferred with hydrophilicity by prior plasma oxidation (10 min). After modification, the electrode was dried at $4^{\circ} \mathrm{C}$ for $18 \mathrm{~h}$. Rotating disc cyclic voltammetry was performed on an electrochemical analyzer (BSA $50 \mathrm{~W}$ ). The electrode was rotated at $8000 \mathrm{rpm}$, using a rotator (RDE-2, BAS), to observe the catalytic activity-limited current. Platinum wire counter and $\mathrm{Ag}|\mathrm{AgCl}|$ sat. $\mathrm{KCl}$ reference electrodes were used. All measurements were performed at $37^{\circ} \mathrm{C}$ in a thermostated water jacket-equipped electrolysis cell. The electrolysis solution was comprised of $0.1 \mathrm{M}$ phosphate buffer ( $\mathrm{pH} \mathrm{7}$ ) in a total volume of $20 \mathrm{~mL}$.

\section{Results and Discussion}

Fig. 1A depicts the cyclic voltammograms for the hydrogel electrodes prepared with GOx and polymer II on an MgOC-E (blue curve (a)) or a GC-E (red curve (b)), in the presence and absence (gray curve (c)) of $0.5 \mathrm{M}$ glucose, with a total hydrogel loading of $1000 \mu \mathrm{g} \mathrm{cm}^{-2}$ at $37^{\circ} \mathrm{C}$. The symmetric voltammogram observed in the absence of glucose (gray dashed-curve (c)) indicates that the formal potential is $-0.022 \mathrm{~V}$ vs. $\mathrm{Ag} \mid \mathrm{AgCl}$ and that the total surface density of the Os complex is $2 \times 10^{-7} \mathrm{~mol} \mathrm{~cm}^{-2}$, indicating that most of the Os complex applied to the electrode is involved in the surface redox reaction. The onset potential of the glucose oxidation current was observed to be $-0.12 \mathrm{~V}$ vs. $\mathrm{Ag} \mid \mathrm{AgCl}$, and the current reached a steady state at $0.3 \mathrm{~V}$. The steady-state glucose oxidation current on the $\mathrm{MgOC}-\mathrm{E}$ was determined to be $45 \pm 7 \mathrm{~mA} \mathrm{~cm}^{-2}$, which is almost 20 times higher than that for the GC-E (red curve (b), $2.3 \pm 0.1 \mathrm{mAcm}^{-2}$ ). The current density at $0 \mathrm{~V} \mathrm{vs}$. $\mathrm{Ag} \mid \mathrm{AgCl}$ is $15 \mathrm{~mA} \mathrm{~cm}^{-2}$, while at the same potential, the hydrogel electrode comprising conventional polymer $\mathbf{I}$ is not able to produce any current (Table 1) [1,2,4-6].

The steady-state catalytic glucose oxidation process depends on the hydrogel composition, as shown in Fig. 1, panel B. At a constant total hydrogel loading of $1000 \mu \mathrm{g} \mathrm{cm}^{-2}$, the highest current densities, $50 \pm 8$ and $50 \pm 6 \mathrm{mAcm}^{-2}$, are observed for hydrogel GOx:polymer:crosslinker compositions of 40:40:20 and 42.5:42.5:15 respectively. As the percentage weight of the crosslinker increases from $10 \%$ to 15 or $20 \%$, although the content of the biocatalyst decreases, the efficiency of current production increases. The stability of the continuous current response improves as the weight ratio of crosslinker increases $[15,16]$. In presence of $10 \mathrm{wt} \%$ crosslinker, the current density was observed to decrease by $40 \%$ after the electrode has rotated at $8000 \mathrm{rpm}$, at $37^{\circ} \mathrm{C}$, for 5 minutes. Under the same operating conditions, almost $90 \%$ of the initial current remains for the electrodes made with hydrogel samples containing $15 \%$ or $20 \%$ crosslinker.

Fig. 2 (panel A) shows the dependence of the glucose oxidation current on hydrogel loading. The catalytic current increases linearly, to a loading of $1000 \mu \mathrm{g} \mathrm{cm}^{-2}$, owing to the high surface

Table 1

Comparison of the construction and performance of some recent hydrogel-porous carbon-based glucose electrodes.

\begin{tabular}{|c|c|c|c|c|c|c|c|c|c|c|}
\hline $\begin{array}{l}\text { Ref. } \\
\text { No. }\end{array}$ & Enzyme & Polymer & Hydrogel loading & $\begin{array}{l}\text { Electrode } \\
\text { material (carbon) }\end{array}$ & $\begin{array}{l}\text { Buffer (conc., pH, } \\
\text { temp.) }\end{array}$ & Temp. & $\begin{array}{l}\text { Glucose } \\
\text { conc. }\end{array}$ & $\begin{array}{l}\text { Electrode } \\
\text { rotation rate }\end{array}$ & $\begin{array}{l}\text { Onset potential vs. } \\
\mathrm{Ag} \mid \mathrm{AgCl} / \mathrm{V}\end{array}$ & Current density \\
\hline$[1]$ & GOx & $\begin{array}{l}\text { Polymer } \\
\text { I }\end{array}$ & $1000 \mu \mathrm{g} \mathrm{cm}^{-2}$ & MgOC on GC & $0.1 \mathrm{M} \mathrm{PB}, \mathrm{pH} 7$ & $37^{\circ} \mathrm{C}$ & $500 \mathrm{mM}$ & $8000 \mathrm{rpm}$ & 0.05 & $\begin{array}{l}60 \mathrm{~mA} \mathrm{~cm}^{-2} \\
@ 0.7 \mathrm{~V}\end{array}$ \\
\hline [2] & $\begin{array}{l}\text { d- } \\
\text { FADGDH }\end{array}$ & Polymer & $1600 \mu \mathrm{g} \mathrm{cm}^{-2}$ & MgOC on GC & $1 \mathrm{M} \mathrm{PB}, \mathrm{pH} 7$, & $37^{\circ} \mathrm{C}$ & $500 \mathrm{mM}$ & $9000 \mathrm{rpm}$ & 0.05 & $\begin{array}{l}180 \mathrm{~mA} \mathrm{~cm}^{-2} \\
@ 0.7 \mathrm{~V}\end{array}$ \\
\hline$[4]$ & GOx & $\begin{array}{l}\text { Polymer } \\
\text { I }\end{array}$ & $800 \mu \mathrm{g} \mathrm{cm}^{-2}$ & CNT on $\mathrm{CP}$ & PB, pH 7.1, & $37.5^{\circ} \mathrm{C}$ & $50 \mathrm{mM}$ & $4000 \mathrm{rpm}$ & 0.10 & $\begin{array}{l}22 \mathrm{mAcm}^{-2} \\
@ 0.6 \mathrm{~V}\end{array}$ \\
\hline [6] & GOx & Polymer & $\begin{array}{l}13 \times 10^{-10} \mathrm{~mol} \mathrm{~cm}^{-2} \text { of } \\
\text { Os complex }\end{array}$ & CNT forest & PB, pH 7 & $37.5^{\circ} \mathrm{C}$ & $200 \mathrm{mM}$ & $\begin{array}{l}\text { Stirring the } \\
\text { solution }\end{array}$ & 0.10 & $\begin{array}{l}25 \mathrm{~mA} \mathrm{~cm}^{-2} \\
\text { @ } 0.4 \mathrm{~V}\end{array}$ \\
\hline$[12]$ & GOx & $\begin{array}{l}\text { Polymer } \\
\text { II }\end{array}$ & $200 \mu \mathrm{g} \mathrm{cm}^{-2}$ & $\begin{array}{l}\text { Ketjen black on } \\
\text { GC }\end{array}$ & $\begin{array}{l}20 \mathrm{mM} \text { PB + } 140 \mathrm{mM} \\
\mathrm{NaCl}, \mathrm{pH} 7\end{array}$ & $37^{\circ} \mathrm{C}$ & $100 \mathrm{mM}$ & $6000 \mathrm{rpm}$ & -0.20 & $\begin{array}{l}8 \mathrm{mAcm}^{-2} @ \\
0.3 \mathrm{~V}\end{array}$ \\
\hline [13] & GOx & $\begin{array}{l}\text { Polymer } \\
\text { II }\end{array}$ & $1734 \mu \mathrm{g} \mathrm{cm}^{-2}$ & $\begin{array}{l}\text { Carbonaceous } \\
\text { form }\end{array}$ & $100 \mathrm{mM}$ PB, pH 7.2 & $37^{\circ} \mathrm{C}$ & $50 \mathrm{mM}$ & $2000 \mathrm{rpm}$ & -0.10 & $\begin{array}{l}18 \mathrm{mAcm}^{-2} \\
\text { @ } 0.3 \mathrm{~V}\end{array}$ \\
\hline$[14]$ & d-GOx & Polymer & $200 \mu \mathrm{g} \mathrm{cm}^{-2}$ & GC & $100 \mathrm{mM}$ PB, pH 7 & $37^{\circ} \mathrm{C}$ & $200 \mathrm{mM}$ & $5000 \mathrm{rpm}$ & 0.10 & $\begin{array}{l}5.4 \mathrm{~mA} \mathrm{~cm}^{-2} \\
@ 0.4 \mathrm{~V}\end{array}$ \\
\hline [14] & $\begin{array}{l}\text { d- } \\
\text { FADGDH }\end{array}$ & $\begin{array}{l}\text { Polymer } \\
\text { I }\end{array}$ & $200 \mu \mathrm{g} \mathrm{cm}^{-2}$ & GC & 100 mM PB, pH 7 & $37^{\circ} \mathrm{C}$ & $200 \mathrm{mM}$ & $5000 \mathrm{rpm}$ & 0.10 & $\begin{array}{l}7.5 \mathrm{~mA} \mathrm{~cm}^{-2} \\
\text { @ } 0.4 \mathrm{~V}\end{array}$ \\
\hline \multirow[t]{2}{*}{$\begin{array}{l}\text { This } \\
\text { work }\end{array}$} & GOx & $\begin{array}{l}\text { Polymer } \\
\text { II }\end{array}$ & $1000 \mu \mathrm{g} \mathrm{cm}^{-2}$ & MgOC on GC & $100 \mathrm{mM}$ PB, pH 7 & $37^{\circ} \mathrm{C}$ & $500 \mathrm{mM}$ & $8000 \mathrm{rpm}$ & -0.12 & $\begin{array}{l}50 \mathrm{mAcm}^{-2} \\
\text { @ } 0.3 \mathrm{~V}\end{array}$ \\
\hline & $\begin{array}{l}\text { d- } \\
\text { FADGDH }\end{array}$ & $\begin{array}{l}\text { Polymer } \\
\text { II }\end{array}$ & $1000 \mu \mathrm{g} \mathrm{cm}^{-2}$ & MgOC on GC & 100 mM PB, pH 7 & $37^{\circ} \mathrm{C}$ & $500 \mathrm{mM}$ & $8000 \mathrm{rpm}$ & -0.05 & $\begin{array}{l}8 \mathrm{mAcm}^{-2} @ \\
0.3 \mathrm{~V}\end{array}$ \\
\hline
\end{tabular}

PB: phosphate buffer. 

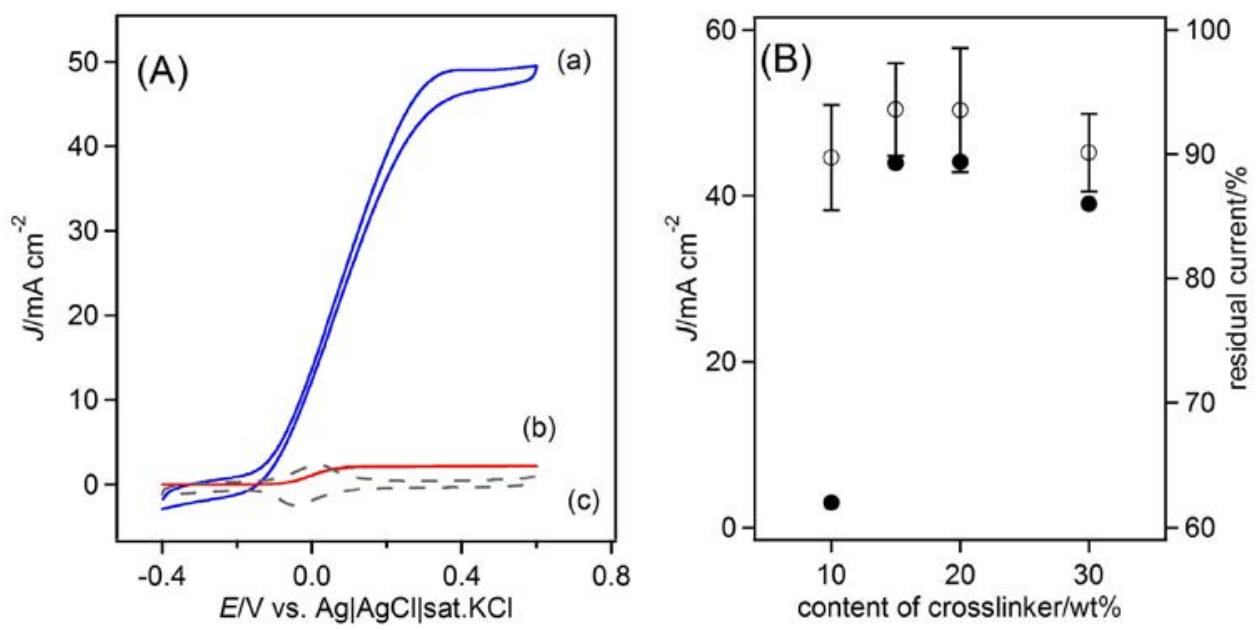

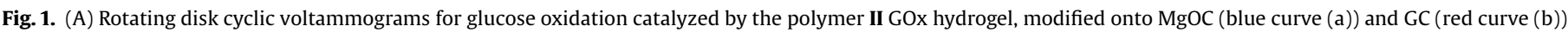

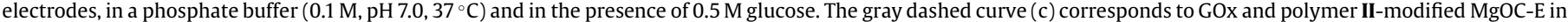

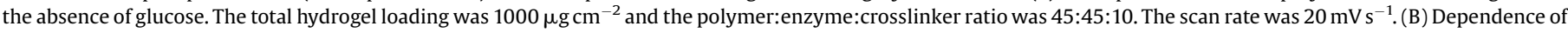

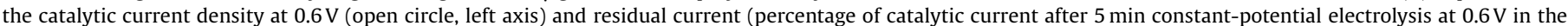

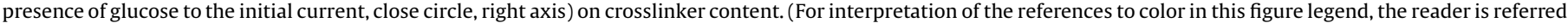
to the web version of this article.)
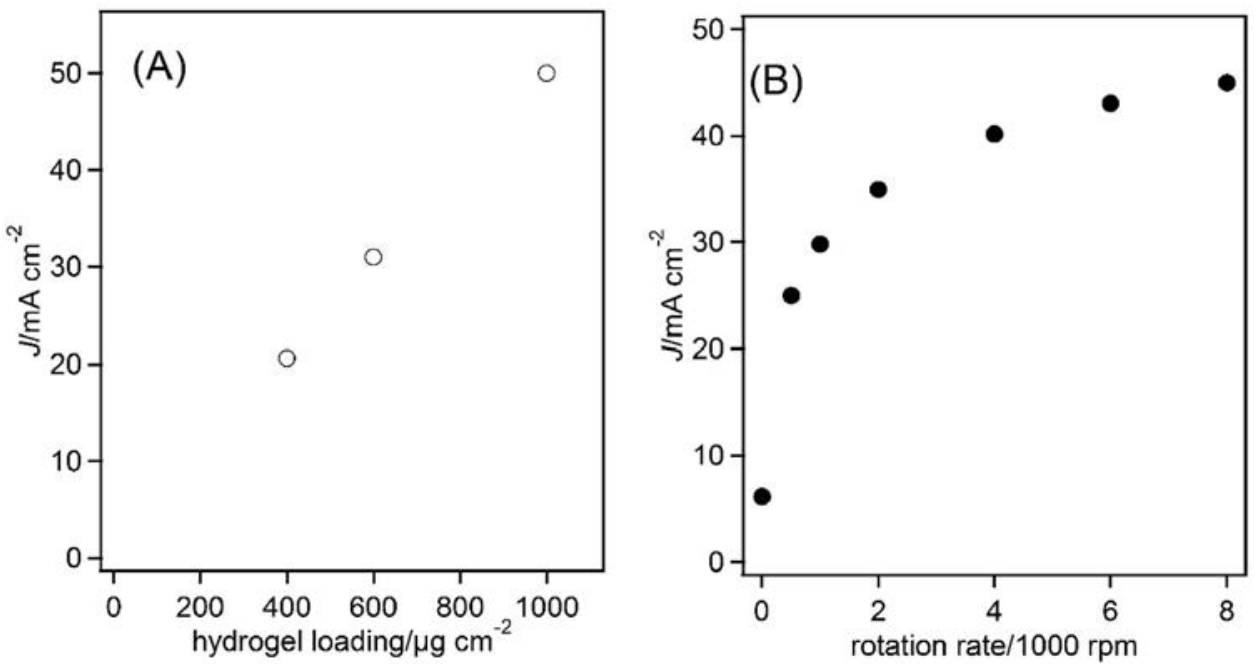

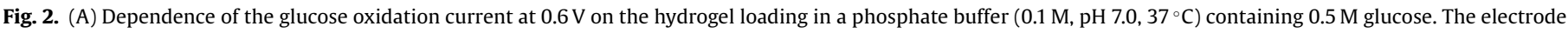

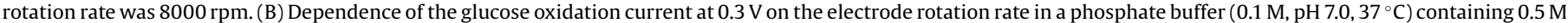
glucose. The total hydrogel loadings were $1000 \mu \mathrm{g} \mathrm{cm}^{-2}$ and the polymer:enzyme: crosslinker ratio was 40:40:20.

area with effective morphology for hydrogel loading. The catalytic current density for the KB-based hydrogel electrode was determined to be $8 \mathrm{mAcm}^{-2}$ at $200 \mu \mathrm{g} \mathrm{cm}^{-2}$ of hydrogel loading, which is in agreement with earlier results [12]. The results suggest that the bioelectrochemical reactions on the $\mathrm{KB}$ and $\mathrm{MgOC}$ electrodes proceed in the same manner at the low hydrogel loading; in this situation hydrogel can be spread over the surface of porous carbon electrode (Fig. 3(a) and (c)). On the other hand, it is difficult to increase the catalytic current for the KB-based electrode by simply increasing the hydrogel loading [12]; the catalytic current for this electrode reached a maximum value at lower hydrogel loading compared to the MgOC-E. Similar results were also observed on a carbon nanotube-modified carbon paper electrode; $22 \mathrm{~mA}$ at $800 \mu \mathrm{g} \mathrm{cm}^{-2}$ of hydrogel loading [4]. In fact, the KB electrode has a large specific surface area that is built by the aggregation of $40 \mathrm{~nm}$ diameter KB particles. Despite this, some areas (spaces) are not utilized to support the hydrogel because the porous carbon structure created by the $\mathrm{KB}$ particles is uniform and not interconnected in a manner that permits the penetration of polymer and enzyme into the entire carbon layer (Fig. 3(b)). On the other hand, electrophoretically deposited MgOC layers have much more effective surfaces for hydrogel loading owing to the presence of $10 \mu \mathrm{m}$-scale interconnected macropores and $38 \mathrm{~nm}$-diameter mesopores, so that the hydrogel layer can be widely distributed on the carbon layer, while mass transfer of fuel are not limited (Fig. 3(d)) [2].

Fig. 2 (panel B) shows the dependence of the glucose oxidation current, at $0.3 \mathrm{~V}$, on the electrode rotation rate. The catalytic current showed a significant increase as the rotation rate is increased to $500 \mathrm{rpm}$ that plateaued asymptotically beyond $1000 \mathrm{rpm}$. At low rotation rates (i.e. $500 \mathrm{rpm}$ ), $60 \%$ of the maximum glucose oxidation current is observed, which indicates that mass transfer through the MgOC-E layer is effective [12]. The threedimensional macro-cellular carbonaceous foam electrode, 
A)

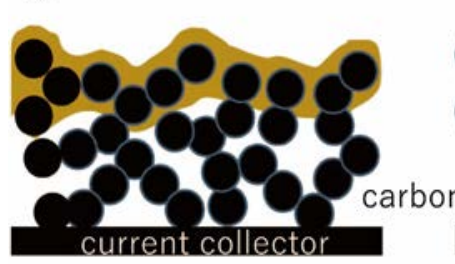

B)

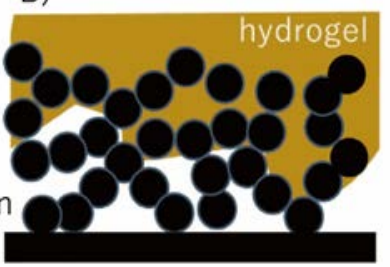

C)

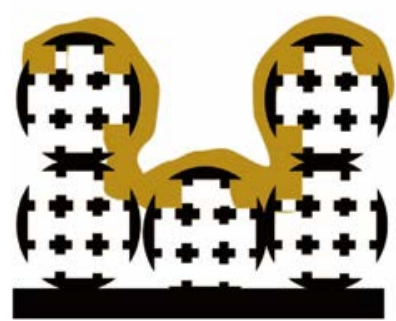

D)

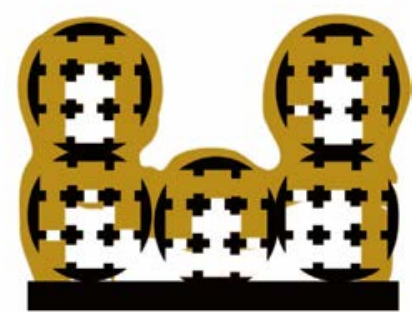

Fig. 3. Proposed schematic illustration of hydrogel distribution within porous carbon electrode. Porous carbon with random pore size (like $\mathrm{KB}$ ) with low hydrogel loading (A) and high loading (B), and pore size-controlled porous carbon electrode (MgO-templated carbon) with low hydrogel loading (C) and high loading (D).

modified with $1734 \mu \mathrm{g} \mathrm{cm}^{-2}$ of hydrogel, generated a current density of $18 \mathrm{~mA} \mathrm{~cm}^{-2}$ at $37^{\circ} \mathrm{C}$ and $2000 \mathrm{rpm}$ [13]. In comparison, the MgOC-E generated double the current density $\left(35 \mathrm{~mA} \mathrm{~cm}^{-2}\right)$ at $2000 \mathrm{rpm}$ and lower hydrogel loading $\left(1000 \mu \mathrm{g} \mathrm{cm}^{-2}\right)$. The higher current density can be ascribed to highly efficient electron transport through the thin hydrogel layer $[17,18]$, as well as the hierarchical electrode morphology. Macro-structures among the unevenly deposited carbon particles allow for the smooth mass transfer of glucose through the carbon layer, while the $38 \mathrm{~nm}$ mesoporous structure allows for the formation of very thin hydrogel structures, reducing mass transfer resistance through the hydrogel as glucose passes from solution to the enzyme (Fig. 3(d)). The maximal catalytic current density, at infinite rotation rate, that can be reached when glucose is sufficiently delivered to the catalytic site of the modified hydrogel, was estimated from the intercept of the Koutecky-Levich plot (1/current density vs. 1/ $\left(\text { radian } \mathrm{s}^{-1}\right)^{1 / 2}$ ). The maximal current density for MgOC-E, with $1000 \mu \mathrm{g} \mathrm{cm}^{-2}$ of hydrogel, was determined to be $60 \mathrm{mAcm}^{-2}$, which is $\sim 6$-fold higher than that for the KB electrode with a loading $200 \mu \mathrm{g} \mathrm{cm}^{-2}$ [12]. The diffusion coefficient of glucose, estimated from the slope of the plot, is $2.8 \times 10^{-7} \mathrm{~cm}^{2} \mathrm{~s}^{-1}$, which is of the same order of magnitude than that for the KB electrode (3.7 $\times 10^{-7} \mathrm{~cm}^{2} \mathrm{~s}^{-1}$ on $100 \mathrm{mM}$ glucose) [12]. These results suggest that there are no distinct differences between $\mathrm{MgOC}$ and $\mathrm{KB}$ in current production efficiency, but $\mathrm{MgOC}$ is the better platform, having a larger capacity for hydrogel loading.

Fig. 4 presents a comparison of the cyclic voltammograms for the various hydrogel electrodes on MgOC-E, using the highpotential polymer I $(0.22 \mathrm{~V})$, and the low-potential polymers II $(-0.03 \mathrm{~V}$, with long spacer chain). Although the redox potential of the hydrogel with polymer II is more reducing than that of polymer $\mathbf{I}$, and close to the redox potential of GOx, the difference in their steady-state catalytic currents was quite small. The long carbon chain linking the Os complex with the backbone polymer allows the redox center to collect electrons more efficiently from the GOx active center $[17,18]$. In addition, the macro-meso-hierarchal structure of the MgOC-E was also very effective for producing a hydrogel electrode redox polymer with low potential. In previous papers we demonstrated that polymer I-based hydrogels

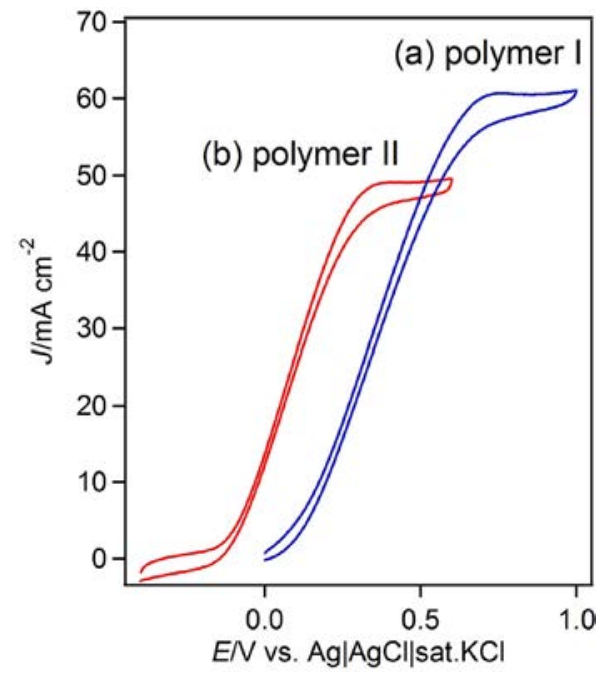

Fig. 4. Rotating disk cyclic voltammogram for glucose oxidation by a GOx-hydrogel modified MgOC-E in phosphate buffer $\left(0.1 \mathrm{M}, \mathrm{pH} 7.0,37^{\circ} \mathrm{C}\right)$ containing $0.5 \mathrm{M}$ glucose, using polymer I (blue curve (a)), and polymer II (red curve (b)). Total hydrogel loadings were $1000 \mu \mathrm{g} \mathrm{cm}^{-2}$ and the polymer:enzyme:crosslinker ratio was 45:45:10 for polymer I and polymer II.(For interpretation of the references to color in this figure legend, the reader is referred to the web version of this article.)

incorporating deglycosylated FAD-dependent glucose dehydrogenase (d-FADGDH, from A. terreus, Ikeda Tohka, Fukuyama, Japan), produced catalytic currents of 100 and $4 \mathrm{mAcm}^{-2}$ at $25^{\circ} \mathrm{C}$ on MgOC-E and GC-E, respectively [2,14]. Fig. 5(A) shows the cyclic voltammograms for glucose-oxidation using the GOx-hydrogeland d-FADGDH-hydrogel-MgOC-E with polymer II. The catalytic current of the GOx-hydrogel electrode is almost 6 times higher than that of the d-FADGDH-hydrogel electrode $\left(8 \mathrm{mAcm}^{-2}\right)$. Notably, when glycosylated (or non-deglycosylated) FADGDH was used as an alternative to d-FADGDH, no increase in catalytic current is observed. Fig. 5(B) shows the cyclic voltammograms for glucose-oxidation using the GOx-hydrogel- and d-FADGDHhydrogel on GC electrode with polymer II. The ratio of the catalytic current on GOx electrode to that on FADGDH electrode was same in case of MgOC-E and case of GC-E. The comparison indicates that the low catalytic current on FADGDH-polymer II electrode was not due to the electrode material, but to the combination of enzyme and redox polymer. Considering the differences in glucose oxidation current between GOx and FADGDH, it is clear that the long spacer does not lead to more efficient electron capture from the active center in the FADGDH system. Some interactions between the spacer chain and the enzyme surface or enzyme active site might lead to the decreased flexibility of the Os complex in within polymer II in the hydrogel, which is important for the efficient collection of electrons. Although the 3D crystal structure of FADGDH from A. terreus used in this study has not been reported, the structure of the similar FADGDH from $A$. flavus, which shares $60 \%$ of its amino acid sequence homology with FADGDH from $A$. terreus, has recently been reported [19]. By comparison with that from $A$. terreus, the surface of FADGDH would be expected to be more hydrophobic than GOx, and therefore, long hydrophobic spacers may get entangled at the hydrophobic surface of FADGDH by van der Waals forces, or hydrophobic interactions, thereby losing flexibility. In our previous paper, we reported that catalytic current increases with increases in phosphate buffer concentration $(0.1$ to $1 \mathrm{M})$ for a d-FADGDH hydrogel electrode from polymer I [2]. However, the cyclic voltammogram of the hydrogel modified electrode made 

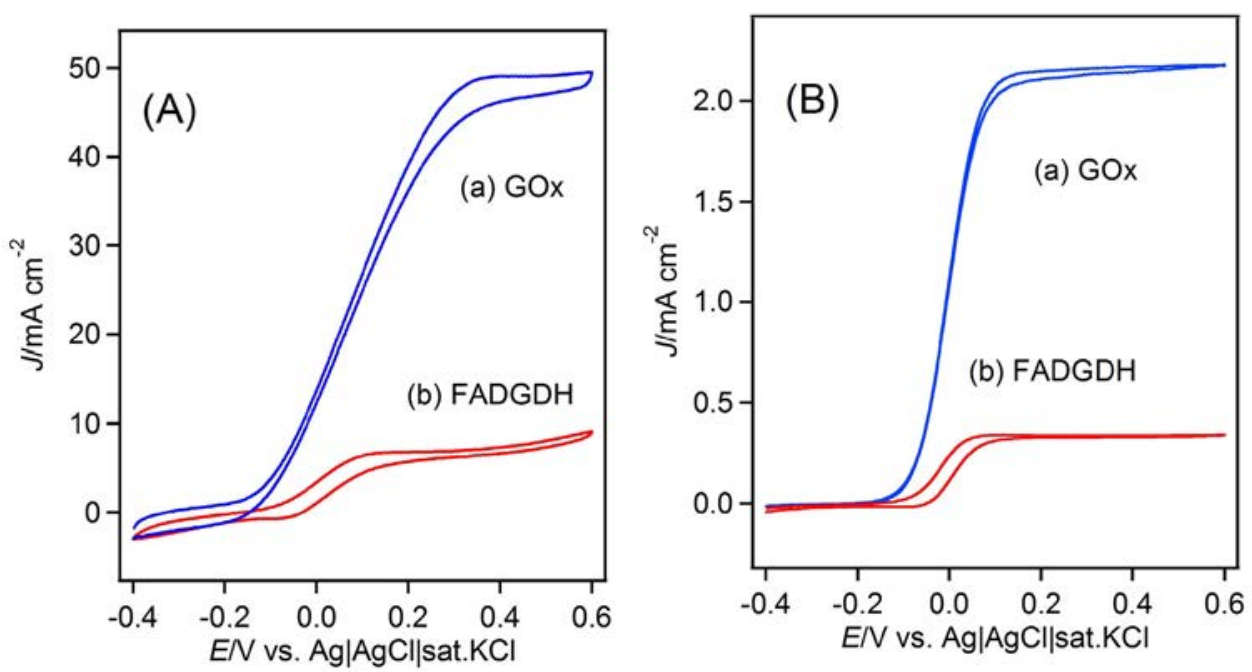

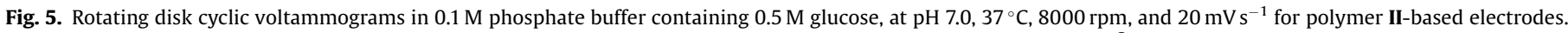

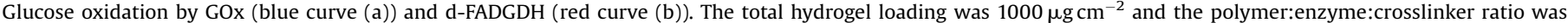
45:45:10 for polymer I and polymer II.(For interpretation of the references to color in this figure legend, the reader is referred to the web version of this article.)

from polymer II remained unchanged when the electrolyte solution was replaced with a $1 \mathrm{M}$ potassium phosphate buffer solution. FADGDH from $A$. terreus can be used with organic mediators with relatively low redox potentials (below $-0.1 \mathrm{~V}$ ), such as naphthoquinones or other redox molecules, at acceptable rates. For example, the bimolecular rate constant for its use with 1,2 -naphthoquionone $(-140 \mathrm{mV})$ is $2-3$ orders of magnitude higher than that of GOx (unpublished). Ross et al. also reported that a 1,2-naphthoquinone-tethered polymer facilitated electron transfer from FADGDH to the electrode, but this was not the case for GOx [20]. The low catalytic current density demonstrated in this study is ascribed to the low affinity of the polymer-tethered Os complex toward the active site of FADGDH. This is still under investigation.

In conclusion, a glucose oxidation current density of $50 \mathrm{~mA} \mathrm{~cm}^{-2}$ was recorded at $0.3 \mathrm{~V}$ using $\mathrm{MgO}$-templated porous carbon, with $38 \mathrm{~nm}$ average diameter pores, modified with a GOx hydrogel, and a redox polymer with a formal potential of $-0.03 \mathrm{~V}$ vs. $\mathrm{Ag} \mid \mathrm{AgCl}$. The onset potential was measured to be $-0.12 \mathrm{~V}$, which is $0.2 \mathrm{~V}$ lower than that reported earlier [1]. Contrary to expectation [14], GOx produces a higher catalytic current than FADGDH or deglycosylated FADGDH. While FADGDHs gathers considerable attentions as an electrochemical biocatalyst for bioelectrochemical application because they don't use $\mathrm{O}_{2}$ as an electron acceptor, FADGDH-Os complex hydrogel systems having both acceptable potentials at which reactions proceed and current density from the viewpoint of application for bioelectrochemical devices, especially for biofuel cell, have not been reported (Table 1 ) so far, nor achieved in this study. When GOx is used as an electrocatalyst in the presence of $\mathrm{O}_{2}$ in the system, hydrogen peroxide can be generated, which may lead an instability of the enzyme electrode and prevent the long-term operation of the bioelectrochemical devices. However, recently we reported that GOx-based hydrogel anode can be stabilized by adding catalase into the hydrogel to eliminate the $\mathrm{H}_{2} \mathrm{O}_{2}$ [1] .

\section{Acknowledgements}

This work was partially supported by a grant from JSPS KAKENHI (Grant Number 15K14684). The author (NM) thanks funding from la Région Aquitaine and the ANR RATIOCELLS (12BS08-0011-01).

\section{References}

[1] A. Suzuki, K. Murata, N. Mano, S. Tsujimura, Bull. Chem. Soc. Japan 89 (2016) 24.

[2] S. Tsujimura, K. Murata, W. Akatsuka, J. Am. Chem. Soc. 136 (2014) 14432.

[3] T.J. Ohara, R. Rajagopalan, A. Heller, Anal. Chem. 65 (1993) 3512.

[4] S. Calabrese Barton, Y. Sun, B. Chandra, S. White, J. Hone, Electrochem. SolidState Lett. 10 (2007) B96.

[5] H. Wen, V. Nallathambi, D. Chakraborty, S. Calabrese Barton, Microchim. Acta 175 (2011) 283.

[6] S. Yoshino, T. Miyake, T. Yamada, K. Hata, M. Nishizawa, Adv. Energy Mater. 3 (2013) 60.

[7] D. Leech, P. Kavanagh, W. Schuhmann, Electrochim. Acta 84 (2012) 223.

[8] P. Pinyou, A. Ruff, S. Pöller, S. Ma, R. Ludwig, W. Schuhmann, Chem. Eur. J. 22 (2016) 5319

[9] P. Kavanagh, D. Leech, Phys. Chem. Chem. Phys. 15 (2013) 4859.

[10] D. MacAodha, P.Ó. Conghaile, B. Egan, P. Kavanagh, C. Sygmund, R. Ludwig, D. Leech, Electroanalysis 25 (2013) 94.

[11] A. Prévoteau, N. Mano, Electrochim. Acta 68 (2012) 128.

[12] E. Suraniti, S. Vivés, S. Tsujimura, N. Mano, J. Electrochem Soc. 160 (2013) G79.

[13] V. Flexer, N. Brun, M. Destribats, R. Backov, N. Mano, Phys. Chem. Chem. Phys. 15 (2013) 6437.

[14] K. Murata, W. Akatsuka, T. Sadakane, A. Matsuaga, S. Tsujimura, Electrochim. Acta 136 (2014) 537.

[15] G. Binyamin, A. Heller, J. Electrochem. Soc. 146 (1999) 2965.

[16] D. MacAodha, M.L. Ferrer, P.Ó. Conghaile, P. Kavanagh, D. Leech, Phys. Chem. Chem. Phys. 14 (2012) 14667.

[17] N. Mano, F. Mao, A. Heller, J. Electroanal. Chem. 65 (2005) 3512.

[18] F. Mao, N. Mano, A. Heller, J. Am. Chem Soc. 125 (2003) 4951.

[19] H. Yoshida, G. Sakai, K. Mori, K. Kojima, A. Kamitori, K. Sode, Sci. Rep. 5 (2015) 13498.

[20] R.D. Milton, D.P. Hickey, S. Abdellaoui, K. Lim, F. Wu, B. Tana, S.D. Minteer, Chem. Sci. 6 (2015) 4867. 